\title{
СОЦІАЛЬНО-ПСИХОЛОГІЧНІ ПОКАЗНИКИ ТРИВОЖНОСТІ УЧНІВ ТА СТУДЕНТІВ СУЧАСНИХ НАВЧАЛЬНИХ ЗАКЛАДІВ РІЗНИХ ТИПІВ
}

\author{
Кандидат медичних наук, дочент Тимощук Оксана Василівна, \\ Асистент Токар Ірина Тадеївна, \\ Асистент Кича Ірина Іванівна
}

Україна, Івано-Франківськ, Івано-Франківський начіональний медичний університет; Кафедра гігієни та екологї

DOI: https://doi.org/10.31435/rsglobal_ws/30042019/6474

\section{ARTICLE INFO}

Received: 19 February 2019

Accepted: 21 April 2019

Published: 30 April 2019

\section{KEYWORDS}

socio-psychological indicators, anxiety,

students,

Spielberger's technique.

\begin{abstract}
In conditions of modern daily stresses and ecologically unfavorable external factors, the level of anxiety becomes one of the leading indicators of the personality development. Anxiety predominates in the lives of modern students and very often causes a decrease in work capacity, labor productivity, communication problems and can lead to the development of various somatic diseases.

At this stage, the level of anxiety becomes one of the driving factors of a number of psychological problems and is considered as an "anterior neurotic condition" and is an initial stage in behavioral disorders. Correction of anxiety and its dispel are very important in preparing students for difficult life and study situations and for learning new work. A present the number of anxious boys and girls has increased; they show signs of anxiety, uncertainty, and emotional instability. The results of recent research indicate both the increase in the number of anxious young people in comparison with the last decade, and the change in the form of anxiety, which seems to be "matured", it has become deeper and more personal.
\end{abstract}

Citation: Тимощук О. В., Токар I. Т., Кича I. I. (2019) Socio-Psychological Indicators Ofanxiety of Students at Modern Educational Establishments of Different Types. World Science. 4(44), Vol.2. doi: 10.31435/rsglobal_ws/30042019/6474

Copyright: (C) 2019 Тимощук О. В., Токар I. Т., Кича I. I. This is an open-access article distributed under the terms of the Creative Commons Attribution License (CC BY). The use, distribution or reproduction in other forums is permitted, provided the original author(s) or licensor are credited and that the original publication in this journal is cited, in accordance with accepted academic practice. No use, distribution or reproduction is permitted which does not comply with these terms.

Вступ. Період старшого шкільного віку та студентські роки є достатньо неординарним періодом життя людини, оскільки відбувається перехід до дорослого середовища, стають чіткими позиції світогляду, відбуваються процеси стабілізації стосунків 3 однолітками, викладачами i батьками, самооцінка набуває адекватності, форми поведінки стають менш негативістськими. У старшому шкільному та студентському періоді формується чітке сприйняття відповідальності та виникає проблема вибору майбутньої професії і побудова планів на подальше доросле життя, а також мрії про особисті стосунки та сім'ю, що є досить важким завданням для сучасної молоді. Крім того, також зростає кількість навчальних навантажень, вимог до поведінки, очікування від підлітків дорослих вчинків та відповідальності, які у своїй сукупності мають суттєвий вплив на їх свідомість. На даному етапі життя виникає багато страхів: бути невизнаним, не виправдати батьківських сподівань, не реалізувати власні плани, невпевненість у своєму майбутньому та невідомість подальшого розвитку подій власного життя сприяють розвитку підвищеного рівня тривожності серед учнів та студентів. Тому, особливої актуальності набуває не лише визначення рівня тривожності юнаків та дівчат, а й проведення аналізу факторів, які визначають загальний рівень особистісної та ситуативної тривожності у чітко окреслених ситуаціях. 
Теоретичні аспекти тривожності обумовлюють поведінку суб'єкта. Наявність якогось базового рівня тривожності $\epsilon$ нормальною і обов'язковою особливістю особистості, який $\epsilon$ оптимальним та бажаним для кожної окремої людини і трактується як корисна тривожність. Особистісна тривожність - це стійка особистісна риса, яка попереджує розвиток схильності до тривоги і забезпечує можливість аналізувати широкий спектр ситуацій як загрозливі, і в той же час, забезпечувати відповідь на кожну 3 них конкретною реакцією. Дана особливість активується за наявності подразників, які інтерпретуються як загрозливі для самооцінки та самоповаги. Оцінка ситуативної тривожності відбувається за рахунок суб'єктивно пережитих емоцій напруження, стурбованості, заклопотаності, знервованості, які виникають в результаті відповіді на стресову ситуацію і мають різну інтенсивність і тривалість. Високотривожні індивідууми схильні побачити загрозу власній самооцінці і самоповазі у багатьох ситуаціях i відповідати на ці ситуації вираженою тривогою, особливо стосовно загрози компетенції і престижу. На даний момент єдиною методикою, яка дає можливість диференційовано визначати тривожність і як властивість, і як стан особистості є методика Ч. Д. Спілбергера, яку російською мовою адаптував Ю. Л. Ханін.

Термін «тривожність» може характеризуватися наступними формами прояву: короткотривала емоційна реакція страху, психічний стан та властивість особистості, яка впливає на кругозір та прийняття рішень. Тривога - це емоційний стан, що з'являється в умовах небезпеки і характеризується станом очікування несприятливого розвитку подій, високого рівня стурбованості, емоційної напруги. Прояви тривожності $\epsilon$ соматичні (прискорене серцебиття, схвильоване дихання, тремор, підвищення артеріального тиску, підвищена збудливість і ін.) і поведінкові (прояви апатії чи демонстрація жорстокості). Розрізняють також „маски тривожності” - агресія, апатія, постійна замріяність, лінь. Певний рівень тривожності конкретної людини - це корисна тривожність. Однак, високий рівень тривожності протягом постійного часу, негативно впливає на життєдіяльність і розвиток особи, оскільки така людина емоційніше реагує на свої невдачі, її працездатність різко знижується в надзвичайних ситуаціях чи обмеженні часу, а страх перед невдачами заважає досягати успіху в житті.

Психологічні причини тривоги поділяються на суб'єктивні (невпевненість у кінцевому результаті подій) і об'єктивні (втома, переживання про стан власного здоров'я, зміни психіки, вживання медикаментів). Тривожність підлітків залежить від їх психофізіологічними та особистісних особливостей і виникає внаслідок підліткової кризи, яка пов'язана 3 дисгармонією розвитку, дезорганізує молодих людей та суттєво впливає на якість їх життя та формування основних соціогенних поглядів. Здобування освіти значною мірою впливає на психіку, становлення особистості, окреслює склад мислення. В той же час умови навчання в сучасних закладах освіти є територією для тренування певних адекватних реакцій на постійний вплив соціального та фізичного середовища існування. Для успішного навчання потрібний високий рівень інтелекту, ерудованості, володіння певним логічним складом мислення або високий рівень працездатності, наполегливість, мотивація. Від рівня початкової тривожності залежить успішність, яка допомагає при вирішенні простих завдань і $є$ перепоною при розв'язанні складних. У соціальному аспекті тривожність визначає рівень комунікабельності та впливає на спілкування молоді 3 однолітками, часто стаючи причиною конфліктів, а у психологічному аспекті - визначає низький рівень самооцінки, нерішучість, невпевненість у власних силах, демотивацію.

Мета статті: виявити соціально-психологічні показники негативного впливу особистісної та ситуативної тривожності на учнів та студентів сучасних навчальних закладів різних типів.

Матеріали і методи. У процесі вивчення соціально-психологічних показників тривожності на учнів та студентів сучасних навчальних закладів різних типів здійснювали дослідження у п'ятьох сучасних закладах освіти м. Івано-Франківська: Прикарпатський національний університет імені Василя Стефаника, Івано-Франківський фінансово-комерційний кооперативний коледж імені С. Граната, Івано-Франківське музичне училище імені Дениса Січинського, Івано-Франківський професійний ліцей автомобільного транспорту і будівництва №15, Івано-Франківський ліцейінтернат для обдарованих дітей з сільської місцевості. У ході роботи проведено обстеження 300 учнів та студентів (в тому числі 150 дівчат та 150 юнаків).

Оцінку рівня тривожності проводили за допомогою методики Ч.Д. Спілберга, Ю.Л. Ханіна, яка дає можливість оцінити особистісну та реактивну тривожність, а також більш специфічні іiі реакції. На даний час методика, запропонована Ч.Д. Спілбергером є єдиною методикою, яка дає можливість диференціювати тривожність і як особистісну характеристику, i як стан. Широко застосовується у нашій країні російськомовна версія STAI для визначення 
рівня реактивної та особистісної тривожності Спілбергера - Ханіна $(1976,1978)$, яка є перевіреним і високоінформативним показником самооцінки ступеня тривожності в певний момент (реактивна тривожність) i ступеня тривожності протягом життя індивідуума (особистісна тривожність). Відповідно до даної методики тривогу розцінюють як стан, а тривожність як характеристику особистості, яка має суттєвий вплив поведінку особистості.

Опитувальник може бути застосований як для індивідуальних, так і для групових досліджень. Час тестування складає приблизно 5-8 хв. Найчастіше воно проводиться фронтально - одразу з певною групою, за умови чіткого контролю виконання поставлених завдань кожним учасником. Оцінка та трактування результатів тесту відбувається за чітко визначеним алгоритмом. Якщо учень чи студент відповів менше ніж на 18 запитань 3 кожного варіанта опитувальника, то опрацювання та оцінка даного досліджуваного не проводиться. В залежності від потреби, можна використовувати одну або дві шкали. Шкала самооцінки має дві частини, за показниками результатів яких проводиться оцінка реактивної (РТ, вислови № 1-20) і особистісної (ЛТ, вислови № 21-40) тривожності. Результатів самооцінки по кожній з підшкал може мати значення від 20 до 80 балів. Слід відмітити, що вищі значення величини підсумкових показників, вказують на вищий рівень ситуативної або особистісної тривожності. Для оцінки отриманих показників застосовують наступну градацію (табл. 1):

Таблиця 1. Норми для оцінки рівня тривожності

\begin{tabular}{|c|c|c|}
\hline \multicolumn{3}{|c|}{ Рівні тривожності (в балах) } \\
\hline Низький & Середній & Високий \\
До 30 балів & $31-45$ балів & 46 і більше балів \\
\hline
\end{tabular}

Високі рівні реактивної тривожності можуть бути причиною зниження та концентрації уваги і навіть причиною відхилень тонкої координації рухів. Натомість, дуже низькі рівні реактивної тривожності може негативно впливати на результати діяльності індивідуума. Реактивна тривожність найчастіше розвивається як емоційна реакція у відповідь на певний стресовий фактор. Найчастіше значення показників реактивної тривожності досягають особливо високих чи особливо низьких величин напередодні значущих важливих подій у житті (зустрічі, виконання важливих завдань, змагання, виступи перед аудиторією). Тривожність також може розвиватися внаслідок пережитих життєвих подій, емоції від яких мають суттєвий і тривалий впливу на особу.

Високий рівень особистісної тривожності прямо пропорційно залежить від існування невротичного конфлікту, присутності емоційних і невротичних зривів, а також наявності психосоматичних захворювань. У якості схильності особистісна тривожність особливо яскраво проявляється при виникненні у іï житті небезпечних ситуацій, які можуть бути загрозою їі престижу, самооцінки, самоповаги, рейтингу в колективі тощо.

Потрібно звертати увагу на істотні відхилення від значень показників помірної тривожності, оскільки іiї високі рівні можуть бути причиною виникнення стану тривоги щодо оцінки iі компетентності. За таких обставин необхідно максимально можливо знизити суб'єктивну значущість обставин і завдань та зосередитися на створенні умов, за яких буде відчуватися максимальна впевненість в успіху кожного починання.

При низькому рівні вираження тривожності, необхідно максимально зосередитися на мотивах діяльності і працювати над розвитком підвищення почуття відповідальності за кожний конкретний вчинок. Проте, бувають випадки, коли дуже низький рівень тривожності зумовлений прагненням людини активно витіснити високу тривогу, для того, щоб презентувати свою особу з найкращого боку.

Психологічний розвиток особистості юнаків та дівчат являє собою діалектичний процес становлення і розв'язання протиріч, перенесення зовнішніх емоцій та переживань всередину, формування самоповаги та заохочення для роботи над собою. На відміну від дорослих, у юнацькому віці особливо гостро виникає потреба в досягненнях та самореалізації, які учні та студенти активно прагнуть реалізувати у процесі навчальної діяльності. У разі виникнення труднощів у процесі успішного самоствердження в процесі навчання в сучасних закладах освіти, юнаки та дівчата починають активно себе реалізовувати в інших сферах життя: спорт, хоббі, бізнес, тощо. Дана ситуація виникає внаслідок гострої природньої потреби людини 
відшукати для себе успішну галузь та досягнути в ній успіхів, оскільки при порушенні даних взаємозв'язків можливий розвиток невротичних станів та розвиток соматичних захворювань.

Виходячи 3 характерних особливостей юнацького віку, можна говорити про нього, як про складний період у житті особистості, на якому відбувається остаточне формування фізичного та психічного розвитку юнаків та дівчат, а також відбуваються основні процеси становлення особистості і всього подальшого життя. На перший план виступає найважливіше прагнення молодих людей почувати себе значущим, бажання продуктивно i якісно спілкуватися $з$ людьми. Оскільки закрита в собі, закомплексована, нетовариська особа, яка постійно перебуває в стані очікування в усьому проявів невдач, постійно відчуває дискомфорт і не може створювати якісних стосунків у середовищі існування. Власне цим важливим процесам та вдалому безболісному проходженні важливого етапу у житті учнів та студентів можуть заважати високі значення показників рівня тривожності.

Результати досліджень. Проводячи аналіз основних показників особливостей формування особистісних ознак та корелят ПсА особистості в умовах впливу стресогенних чинників, якими визначаються сучасні навчальні заклади різних типів освіти, необхідно звертати увагу на основні показники тривожності юнаків і дівчат. Саме основні характеристики тривожності впливають за емоційний стан і основні характеристики поведінки і $є$ основою для ефективної організації продуктивної щоденної навчальної та навчально-професійної діяльності та забезпечують умови для їх активного та результативного розвитку. Період появи ознак тривожності можна вважати донозологічною ознакою формування та розвитку змін процесів ПсА, порушень стану психічного здоров'я тощо.

У наш час виділяють два основних види тривожності: СТ і ОТ, які виникають внаслідок здійснення певного конкретного виду діяльності, наприклад навчання. СТ $є$ основною характерологічною ознакою загальної тривожності і спричиняє появу особливих проявів емоційних реакцій юнаків і дівчат у даний момент як ціленаправлену відповідну реакцію на подразнюючу дію різних стресових ситуацій. ОТ $є$ відносно стійкою індивідуальною ознакою людини, яка характеризує більшу чи меншу схильність до проявів тривоги, загального емоційного напруження, особливостей тривожного сприйняття ситуацій оточуючого середовища i появу тривожнісних реакцій в процесі виконання стереотипних актів та забезпечення певних умов щоденної діяльності. Навчальну тривожність характеризують як особливу форму прояву емоційного стресу учнів та студентів, який нерозривно пов'язаний з впливом на них деяких ситуацій навчального процесу та їх результатів, а також особливостей взаємовідносин 3 педагогами, ровесниками та батьками.

При виконанні дисертаційної роботи та оцінці результатів тесту особистісного опитувальника Спілбергера та вивчення окремих емоційних відповідей юнаків та дівчат у певний визначений період часу, було виявлено, що ії значення за критеріальними показниками складали $39,17 \pm 0,83$ бали у юнаків та $41,30 \pm 1,15$ балів $(2,4 \%$; $\mathrm{p}(\mathrm{t}) \mathrm{yH}>0,05)$ у дівчат університету, $39,47 \pm 0,86$ балів у юнаків та $42,43 \pm 0,69$ балів $(3,2 \% ; \mathrm{p}(\mathrm{t}) \pi>0,05)$ у дівчат ліцею, $38,63 \pm 0,86$ балів у юнаків та $39,73 \pm 1,20$ балів $(3,6 \% ; \mathrm{p}(\mathrm{t}) \mathrm{yч}>0,05)$ у дівчат училища, $41,77 \pm 0,73$ балів у юнаків та $42,90 \pm 0,83$

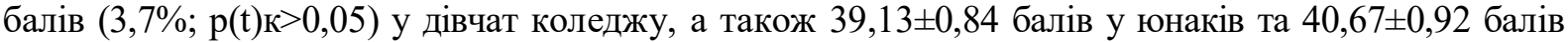
$(4,4 \% ; \mathrm{p}(\mathrm{t}) ш>0,05)$ у дівчат школи (рис. 1$)$.

Необхідно звернути увагу на те, що найвищі значення показників прояву ознаки основних характеристик ОТ, на відміну від значень показників СТ, були виявлені серед юнаків та дівчат ліцею, що може бути ознакою присутності у них саме у цей період часу високого рівня особистісно-зумовленої тривожності, психоемоційного напруження, та стурбованого ставлення до певних факторів навколишнього середовища. Найнижчі показники ознак основних характеристик ОТ були відмічені серед юнаків училища та дівчат школи.

Отож, найшвидші зміни досліджуваних ознак, які характеризувались позитивним змістом, були виявлені серед юнаків та дівчат школи, а найшвидші зміни досліджуваних ознак, які характеризувались негативним змістом, були відмічені серед учнів і студентів коледжу.

Необхідно зауважити, що найвищі значення показників СТ були зафіксовані у юнаків та дівчат коледжу, що з високою долею ймовірності може бути ознакою високого прояву ситуативнозумовленого переживання на вплив типових і атипових стресових чинників. Найвищі значення показників СТ були зафіксовані у юнаків і дівчат училища. Найвищі значення показників позитивного змісту, спостерігалися у юнаків та дівчат школи, найзначніші величини показників негативного змісту були характерні $\mathrm{i}$ для юнаків, $\mathrm{i}$ для дівчат коледжу. Серед досліджуваних осіб статистично-значущих та статево-обумовлених відмінностей не було виявлено $\left(\mathrm{p}(\mathrm{t})_{\text {д-ю }}>0,05\right)$. Привертає увагу та особливість, що рівень прояву тривожнісних ознак ситуативного генезу був 
вищий серед дівчат в усіх досліджуваних навчальних закладах сучасних типів.

Показники змін основних параметрів ОТ учнів та студентів, мали дещо інші значення і характеризували ступінь схильності юнаків і дівчат до проявів таких тривожнісних реакцій, як сильне занепокоєння, високе емоційне напруження тощо. Величина значень основних тривожнісних характеристик особистісного характеру для усіх груп відповідно становив: $39,93 \pm 0,77$ бали у юнаків та $40,60 \pm 1,12$ балів $(3,1 \%$; $\mathrm{p}(\mathrm{t}) \mathrm{yH}>0,05)$ у дівчат університету, $42,60 \pm 1,14$ балів у юнаків та $43,13 \pm 0,99$ балів $(2,4 \% ; \mathrm{p}(\mathrm{t}) л>0,05)$ у дівчат ліцею, $39,53 \pm 0,88$ балів у юнаків та $40,20 \pm 0,08$ балів $(3,1 \% ; \mathrm{p}(\mathrm{t}) \mathrm{yч}>0,05)$ у дівчат училища, $40,70 \pm 0,99$ балів у юнаків та $41,50 \pm 1,11$ балів $(2,5 \% ; \mathrm{p}(\mathrm{t}) \kappa>0,05)$ у дівчат коледжу, а також $40,43 \pm 0,83$ балів у юнаків та $39,63 \pm 0,99$ балів $(4,4 \% ; \mathrm{p}(\mathrm{t}) ш>0,05)$ у дівчат школи (рис. 2$)$.

Необхідно відмітити, що найвищі за величиною прояву основні ознаки ОТ, на відміну від ознак СТ, були виявлені у юнаків та дівчат ліцею, що є підставою для можливості припустити наявність у них саме у даний період часу високого рівня особистісно-зумовленої тривожності, психоемоційного напруження, та неспокійного сприйняття окремих факторів навколишнього середовища. Найнижчі рівні прояву основних характеристик ОТ були відмічені у юнаків училища та дівчат школи.

Отож, найшвидші зміни ознак позитивного значення, були зафіксовані у юнаків та дівчат школи, а найшвидші зміни ознак негативного значення були характерними для учнів $\mathrm{i}$ студентів коледжу.

Висновки. 1. В результаті прведених досліджень рівня особистісної та реактивної тривожності за методикою Спілберга ми встановили, що основна маса юнпків та дівчат мають середній рівень ситуативної та особистісної тривожності. Завдяки цьому, емоційний стан учнів та студентів не має ознак підвищеної напруженості і занепокоєння. У більшості життєвих ситуацій, вони можуть досить часто передбачати свої помилки та керувати власним емоційним станом у складних ситуаціях.

2. Виявлено, що рівень тривожності в основному зумовлює поведінку учнів та студентів, визначає внутрішнє відношення юнаків та дівчат до певного типу ситуації і дає непряму інформацію про особливості взаємин з педагогами, ровесниками, батьками і дорослими.

3. Тривожним особистостям притаманна занижена самооцінка і самоповага, вони постійно сумніваються в собі та власних силах, почуваються самотніми у соціумі, замикаються у собі. Така молодь схильна сприймати ставлення до себе, інших людей і оточуючого середовища в похмурих тонах. Підвищена тривожність впливає на якість спілкування i взаємовідносин з однолітками, часто провокуючи конфлікти та знижуючи рівень мотивації.

4. Таким чином, тривожні учні та студенти, переважно не знаходять визнання серед ровесників, але й не $\epsilon$ ізольованими, вони найчастіше належать до числа найменш популярних, завдяки чому часто можуть бути невпевненими у собі, замкнутими, нетовариськими, або, ж навпаки, виявляти ознаки надмірної говірливості, настирливості, а, іноді і озлобленості. Однією $з$ причин їх непопулярності є відсутність ініціативності через невпевненість у власних силах, що $є$ причиною відсутності можливостей обіймання лідерських позицій в міжособистісних стосунках.

\section{ЛІТЕРАТУРА}

1. Бреслав Г.М. Психологія емоцій: навч. Посібник для вузів. - М.: Академія: Сенс, 2004 - 541 с.

2. Вачков І.В. Основи технології групового тренінгу. Психотехніки: Навчальний посібник. - 3-е изд., Перераб. і доп. - М.: Видавництво «Вісь - 89», 2005. - 256 с.

3. Вікова психологія: Дитинство, отроцтво, юність: Хрестоматія: Учеб. Посібник для студ. пед. Вузів / сост. і. наук.ред. Мухіна В.С., Хвостаков А.А. - М.: Изд. - У центр «Академія» - 2000. - 624 с.

4. Волков Б.С. Психологія юності і молодості: Учеб. Посібник для вузів - М.: Трікста; Акад. Проект 2006. - $255 \mathrm{c}$.

5. Дьяченко М.І. та ін. Психологія вищої школи / М.І. Дьяченко, Л.А. Кандибовіч, С.Л. Кандибовіч. Мн.: Харвест, 2006. - 416 с.

6. Єрмолаєв О.Ю. Математична статистика для психологів: Підручник / - 2-е вид., Испр. - М.: Московський психолого-соціальний інститут: Флінта, 2003. - 336 с.

7. Особливості тривожності сучасних підлітків / Вереніч Н. // Підліток: як йому допомогти. - К. 2004. - C.60-65.

8. Прихожан А.М. Тривожність у дітей та підлітків: психологічна природа і вікова динаміка. - М.: МПСІ Воронеж: НВО «МОДЕК», 2000. - 303 с.

9. Психологические тесты / Под ред. А.А. Карелина: В 2т. - М.: Гуманит. изд. центр ВЛАДОС, 2003. T.1. - 312c. 
10. Психолого-педагогічні аспекти адаптації студентів до навчального процесу у ВНЗ. - Кишинів: ШТІЦА, 1990 -114 с.

11. Савчин М.В.. Василенко Л.П. Вікова психологія: навчальний посібник. - К.: Академвидав, 2005. 360c.

12. Щербатых Ю.В. Психология стресса и методы коррекции. - Спб.: Питер, 2008. - 256с.

13. Al-Fayez GA, Ohaeri JU. Profile of subjective quality of life and its correlates in a nation-wide sample of high school students in an Arab setting using the WHOQOL-Bref. BMC Psychiatry 2011;11:71.

14. Alkhathami S, Kaviani H, Emma S. Social anxiety among adolescents and its relation to quality of life. Eur Proc Soc Behav Sci 2014;218:228.

15. Fehm L, Beesdo K, Jacobi F, Fiedler A. Social anxiety disorder above and below the diagnostic threshold: prevalence, comorbidity and impairment in the general population. Soc Psychiatry Psychiatr Epidemiol 2008;43:257-65.

16. Gultekin B, Dereboy I. The prevalence of social phobia, and its impact on quality of life, academic achievement, and identity formation in university students. Turk Psikiyatr Derg 2011;22:150-8.

17. Izgic F, Akyuz G, Dogan O, Kugu N. Social phobia among university students and its relation to selfesteem and body image. Can J Psychiatry 2004;49: 630-4.

18. Jarallah H Al-Omari F Altowairiqi I Al Saadi K. Magnitude of social anxiety disorder, and impact on quality of life among medical students, taif city-KSA. J Psychol Clin Psychiatry 2017;7.

19. Priyamvada R, Kumari S, Prakash J, Chaudhury S. Cognitive behavioral therapy in the treatment of social phobia. Ind Psychiatry J 2009;18:60-3.

20. Roberts LW, Warner TD, Lyketsos C, Frank E, Ganzini L, Carter D. Perceptions of academic vulnerability associated with personal illness: a study of 1,027 students at nine medical schools. Collaborative Research Group on Medical Student Health. Compr Psychiatry. 2001;42:1-15.

21. Sadock BJ Sadock VA. Kaplan \& Sadock's Synopsis of Psychiatry: Behavioral Sciences/Clinical Psychiatry, 10th Edition. NewYork: Lippincott Williams \& Wilkins; 2007.

22. Timothy J, Atezaz S. Social anxiety disorder: a common unrecognized mental disorder. Am Fam Physician 1999;60: 2311-9.

23. Veale D. Treatment of social phobia. Adv Psychiatr Treat 2003; 9:258-64.

24. Wilson IG. Screening for social anxiety disorder in first year university students: a pilot study. Aust Fam Physician 2005;34. 